\title{
The Negative Imperative in Southern Calabria. Spirito Greco, Materia Romanza Again?
}

\author{
Adam Ledgeway \\ Professor of Italian and Romance Linguistics, Faculty of Modern \\ and Medieval Languages and Linguistics, University of Cambridge, \\ Cambridge, UK \\ anl21@cam.ac.uk
}

Norma Schifano

Lecturer in Modern Languages, Department of Modern Languages, University of Birmingham, Birmingham, UK

n.schifano@bham.ac.uk

\section{Giuseppina Silvestri}

Lecturer in Linguistics, Department of Linguistics, University of California, Los Angeles, USA

g.silvestri@ucla.edu

\begin{abstract}
The aim of this article is to investigate a special case of suppletion in the paradigm of the negative imperative in some dialects of southern Calabria. First, we show how these paradigms involve the extension of an original infinitival desinence to a present indicative verb, giving rise to a hybrid imperatival form (Section 2). Second, we claim that this pattern of suppletion does not represent a Romance-internal development but, rather, the outcome of contact-induced change and, in particular, the influence of the local Greek sub-/adstrate (Section 3). Furthermore, we show that these hybrid patterns also provide significant evidence for the formal morphosyntactic equivalence between competing Greek finite and Romance non-finite forms of subordination, a typical Balkanism (Section 4). Finally, we demonstrate that the extension of the Romance infinitival desinence according to an underlying Greek model yields in synchrony an alternation between a suppletive positive imperative and a true negative imperative, a typologically very rare formal opposition (Section 5 ).
\end{abstract}




\section{Keywords}

negative imperative - suppletion - infinitive - Italo-Greek - Calabrian - language contact

Much attention has been devoted in the literature to the study of imperatival morphology in Romance, and in particular the distribution and nature of true vs. suppletive forms exhibited by positive and negative paradigms, ${ }^{1}$ as exemplified in Table 1.

TABLE 1 Some canonical Romance imperative paradigms ${ }^{2}$

\begin{tabular}{|c|c|c|c|}
\hline & & Positive & Negative \\
\hline \multirow[t]{2}{*}{ Piedmontese } & $2 S G$ & true & true $^{3}$ \\
\hline & $2 \mathrm{PL}$ & [no data] & [no data] \\
\hline \multirow[t]{2}{*}{ modern central Occitan } & $2 S G$ & true & suppletive $[=\mathrm{SBJV}]$ \\
\hline & $2 \mathrm{PL}$ & [no data] & [no data] \\
\hline \multirow[t]{2}{*}{ Spanish, Sardinian } & 2SG & true & suppletive $[=\mathrm{SBJV}]$ \\
\hline & $2 \mathrm{PL}$ & true & suppletive $[=\mathrm{SBJV}]$ \\
\hline \multirow[t]{2}{*}{ French } & 2SG & (true) & (true) \\
\hline & $2 \mathrm{PL}$ & suppletive [=IND] & suppletive [=IND] \\
\hline \multirow[t]{2}{*}{ Catalan } & 2SG & true & suppletive $[=\mathrm{SBJV}]$ \\
\hline & $2 \mathrm{PL}$ & suppletive [=IND] & suppletive [=IND] \\
\hline \multirow[t]{2}{*}{ Italian } & 2SG & true & suppletive $[=\mathrm{INF}]$ \\
\hline & $2 \mathrm{PL}$ & suppletive [=IND] & suppletive [=IND] \\
\hline \multirow[t]{2}{*}{ Romanian } & 2SG & true & suppletive $[=\mathrm{INF}]^{4}$ \\
\hline & $2 \mathrm{PL}$ & suppletive [=IND] & suppletive [=IND] \\
\hline
\end{tabular}

1 See Zanuttini (1994; 1997: Section 4.3), Rivero (1994a; 1994b), Rivero and Terzi (1995), Silva-Villar (1998), Poletto and Zanuttini (2003), Portner and Zanuttini (2003), Manzini and Savoia (2005: 389-487), Maiden (2006), Ionescu (2019), a.o. For further differences exhibited by positive vs. negative imperatives cross-linguistically, see Han (1999; 2001), Tomić (1999), Aikhenvald (2008: $18-20)$.

2 See Rivero (1994b: 91-92), Zanuttini (1997: 109-113), Manzini and Savoia (2005: 461-467), Maiden (2006).

3 The same true > true pattern can be found in Latin for both persons (e.g., (nē) credite (NEG) imagine.IMP.2PL '(don't) imagine!'), later followed by several other strategies, including true > suppletive (e.g., lauda praise.IMP.2SG 'praise!', noli laudare NEG praise.INF 'don't praise!'). See Ionescu (2019: Section 4) for an overview.

4 The infinitive is also attested in old French and in Romansch (Rohlfs, 1968: 356; Tekavčić, 1972: 417), and across numerous Italo-Romance varieties (cf. discussion in Section 4). For 
Following Zanuttini (1997: 105), true imperatives are "verbal forms that are unique to the paradigm of the imperative, in the sense that they are different from any other verbal form used for the same person in any other verbal paradigm", whereas this is not the case with suppletive (or surrogate; cf. Rivero, 1994a) imperatives which involve "verbal forms that are used in the imperative but are morphologically identical to a form used for the same person in another paradigm" such as subjunctives or infinitives (cf. also Rivero, 1994a: 103; Zanuttini, 1994: 119; Isac, 2015: chs 2, 9-10). As Table 1 illustrates, suppletive forms prove particularly common in the negative paradigm, a distribution frequently interpreted as a consequence of the so-called "negative imperative puzzle" (Alcázar and Saltarelli, 2014: Section 2.6.1), ${ }^{5}$ which highlights the fact that true imperatives typically prove incompatible with (preverbal) negators. ${ }^{6}$ Formally, this empirical generalization has been explained in terms of an intervention effect of the preverbal negator: assuming true imperatives are licensed by raising to $C^{\circ}$ (Rivero, 1994b; Graffi, 1996), this movement is blocked by the intervening preverbal negator or by the negator itself lexicalizing the $\mathrm{C}$ position (see further the discussion in Section 4).

Focusing specifically on Italo-Romance, we can identify following Manzini and Savoia (2005: 38gff.) five distinct suppletive types for the 2SG negative imperative, as summarized in Table $2 .{ }^{7}$ Type A (cf. $\mathrm{b}$ ) involves the use of the 3 sg indicative, which also functions as the 2 sg positive imperative (cf. 1a), whereas in Types B-E positive and negative imperatives display distinct forms. In Type $B$ the negative imperative is expressed by the morphological infinitive $(2 b)$, in Type $C$ by the imperfect ( 3 b) or present ( 4 b) subjunctive, in Type $D$ by the auxiliary STAND followed by the lexical infinitive $(5 \mathrm{~b})$, and in Type $\mathrm{E}$ by the gerund optionally introduced by an infinitival auxiliary BE or GO (6b).

further discussion of the suppletive and novel true uses of (the long form of) the infinitive in Romanian, see the discussion around examples (28)-(29) in Section 5 .

5 Cf. also Han (1998; 2001), Zeijlstra (2006), Manzini and Savoia (2005: Section 7.2), Cavalcante (2011).

6 As correctly pointed out by an anonymous reviewer, a related point is the fact that imperatives often feature a different negator than the one used with indicative verbs, not only in cases of subjunctive suppletion for the negative paradigm, where the same irrealis negator is carried over to the imperative (e.g., standard modern Greek), but also in languages featuring a true negative imperative (e.g., the second person singular in Ancient Greek).

7 We gloss over the further internal classification they make in terms of clitic placement and type/position of negation, as well as differences between indicative and the positive imperative forms. We take the second person singular as the model to classify true vs. suppletive negative forms, since cross-linguistically suppletive forms seem to enter paradigms through this particular person first (cf. WALS, map 70A, where only 2 languages out of 547 have true imperative forms for the second person plural but not for the second person singular; http://wals.info/feature/7oA\#2/19.3/148.4). 
TABLE 2 Italo-Romance synthetic and periphrastic suppletive forms for 2SG negative imperative

\begin{tabular}{lllll}
\hline \multicolumn{2}{c}{ Synthetic } & \multicolumn{2}{c}{ Periphrastic } \\
\hline Type A & Type B & Type C & Type D & Type E \\
NEG+IND & NEG+INF & NEG+PRS/ & NEG+stare $(a)$ & NEG+(essere/ \\
& & IPFV.SBJV & 'stand (to)'+INF & andare 'be/go') \\
& & & + GER \\
\hline
\end{tabular}

$(1)$
a. 'kloma
el.
(Donat; Manzini and

call.PRS.IND.3SG [also IMP.2SG] him Savoia, 2005: 446)

'He calls him. / Call him!'
b. 'butfa 'kloma el. NEG call.PRS.IND.3Sg [also IMP.2SG] him

'Don't call him!'

(2) a. 'kerda to 'fre. (La Pli de Mareo; Manzini and Savoia, call.IMP.2SG your brother 2005:390)

'Call your brother!'
b. no (pa) le= ker'de.
NEG PRT him $=$ call.INF

'Don't call him!'

(3) a. 'cama tu 'padre. (Avigliano Umbro; Manzini and Savoia, call.IMP.2sg your father 2005:462) 'Call your father!'
b. $\quad$ nu $\quad l l o=$ ca'massi.
NEG him= call.IPFV.SBJV.2SG
'Don't call him!'

(4) a. 'mutti=li. (Dorgali; Manzini and Savoia, 2005: 463)

call.IMP.2SG $=$ him

'Call him!' 
b. non=lu 'muttaca.

NEG=him call.PRS.SBJV.2SG

'Don't call him!'

(5) a. 'tfama to 'frelu. (Calizzano; Manzini and Savoia, call.IMP.2SG your brother 2005:451)

'Call your brother!'

b. $n \varepsilon \quad s^{\prime} t a=l u \quad$ a tja'ms.

NEG stand.PRS.IND.2SG=him to call.INF

'Don't call him!'

(6) a. cama='jullo. (Miglionico; Manzini and Savoia, 2005: 456)

call.IMP.2SG $=$ him $/$ her $/$ them

'Call him/her/them!'

b. na lo $=$ ca'manno.

NEG him/her/them = call.ger

'Don't call him/her/them!'

Within this scenario we consider below a special case of suppletion in the paradigm of the negative imperative in some dialects of southern Calabria (Section 2). The relevant paradigms are special in several key respects. First, they involve the extension of an original infinitival desinence to a present indicative verb, giving rise to a hybrid imperatival form which exceptionally marries together finite and non-finite inflexional markings. Second, the synchronic comparison of these southern Calabrian varieties allows us a rare opportunity to reconstruct in diachrony the emergence and extension of the relevant suppletive pattern across different persons. Third, the patterns of suppletion in southern Calabria just outlined do not represent a Romance-internal development but, rather, the outcome of contact-induced change and, in particular, the influence of the local Greek sub-/adstrate on the surrounding Romance varieties (Section 3). The resultant system of formal paradigmatic oppositions thus reproduces an underlying Greek model, not a Romance one, giving rise to a case of what Rohlfs famously termed spirito greco, materia romanza ('Greek spirit, Romance material'). At the same time, these Greek-Romance hybrid patterns also provide significant evidence for the formal morphosyntactic equivalence between competing Greek finite and Romance non-finite forms of subordination, a typical Balkan feature, inasmuch as extension of the infinitival desinence never penetrates those imperatival forms introduced by a Greekstyle modal subordinator (Section 4). Finally, the extension of the Romance 
infinitival desinence according to an underlying Greek model, although initially a manifestation of a suppletive pattern, will be shown to yield in synchrony a novel true imperatival pattern and, in turn, an alternation between a suppletive positive imperative and a true negative imperative, a typologically very rare formal opposition (Section 5 ).

\section{$2 \quad$ Negative Imperative in Southern Calabria}

\subsection{Mosorrofa}

Loporcaro (1995) identifies a unique pattern in the negative paradigm of the extreme southern Italian dialect of Mosorrofa (province of Reggio Calabria). Drawing on data from Crucitti (1988), he reports a peculiar inflexional morphology for the first and second person plural, both featuring an (optional) - $r i$ ending. The relevant data set is exemplified in Table 3 with the first-conjugation verb parrari 'speak' (adapted from Loporcaro, 1995: 349).

While the $\mathrm{p}$ (ositive) paradigm displays two patterns, namely one which is syncretic with the indicative (pattern $\mathrm{p}(\mathrm{a}): 2 \mathrm{SG},{ }_{1}{ }_{1} / 2 \mathrm{PL}$ ) and one which exhibits the irrealis modal particle $m i$ plus the present indicative (pattern $\mathrm{p}(\mathrm{b})$ : $3 \mathrm{SG} / \mathrm{PL}$ ), the $\mathrm{n}$ (egative) paradigm operates three patterns, namely one which is syncretic with the indicative (partial pattern $\mathrm{n}\left(\mathrm{a}_{1}\right): 1 / 2 \mathrm{PL}$ without $-r i$ ), the $m i$-form (pattern $\mathrm{n}(\mathrm{b}): 3 \mathrm{SG} / \mathrm{PL}$ ), and one with the infinitive (pattern $\mathrm{n}(\mathrm{c}): 2 \mathrm{SG}$, and optionally pattern $\mathrm{n}(\mathrm{c} 2): 1 / 2 \mathrm{PL}) \cdot{ }^{9}$ To explain the optionality of the -ri suffix with the first and second persons plural, Loporcaro (1995) correctly argues that -ri should be analysed as the erstwhile infinitival ending (cf. parr-a-ri 'stem-thematic.vowel-INF') which has spread to the first and second persons plural via analogical extension from the second person singular because of paradigmatic pressure to restore the structural symmetry between the positive and negative paradigms. In particular, by extending - $r i$ to the first and second persons plural, a paradigm with two patterns $\left(\mathrm{cf} .\left(\mathrm{n}\left(\mathrm{c}_{2}\right): 2 \mathrm{SG}, 1 / 2 \mathrm{PL}\right.\right.$ vs. $\left.\mathrm{n}(\mathrm{b}): 3 \mathrm{SG} / \mathrm{PL}\right)$ is restored

8 Note that the second singular of first-conjugation verbs is syncretic with the third singular of the present indicative.

9 Rohlfs (1968: 355) reports negation + irrealis modal particle also for the second person singular and plural in southern Calabria (cf. also discussion in Section 4):
(i) Nommu
cadi/caditi!
NEG.that ${ }_{\text {IRREALIS }}$
fall.PRS.IND.2SG/PL
'Don't fall!' 


\begin{tabular}{lllll} 
& Positive & Pattern & Negative & Pattern \\
\hline 2SG & parra & $\mathrm{a}$ & non parrari & $\mathrm{c}$ \\
$3 \mathrm{SG}$ & miparra & $\mathrm{b}$ & non mi parra & $\mathrm{b}$ \\
$1 \mathrm{PL}$ & parramu & $\mathrm{a}$ & non parramu $(\boldsymbol{r i})$ & $\mathrm{a}_{1}\left(\mathrm{c}_{2}\right)$ \\
$2 \mathrm{PL}$ & parrati & $\mathrm{a}$ & non parrati $($ ri $)$ & $\mathrm{a}_{1}\left(\mathrm{c}_{2}\right)$ \\
$3 \mathrm{PL}$ & miparrinu & $\mathrm{b}$ & non mi parrinu & $\mathrm{b}$ \\
\hline
\end{tabular}

for the negative imperative exactly mirroring that of the positive imperative (cf. two $\mathrm{p}(\mathrm{a})$ patterns: 2SG, 1/2PL vs. $\mathrm{p}(\mathrm{b}): 3 \mathrm{SG} / \mathrm{PL}$ ). According to Loporcaro, this extension takes place in the negative imperative because this is the only finite paradigm to include an infinitive. Moreover, it is attested exclusively in these dialects (but not in other Romance varieties which also exhibit the infinitive in the second person singular) because of their well-known alternation (and functional equivalence; see Ledgeway, 1998, cf. also De Angelis, 2013: $2 \mathrm{n} .2$ ) between finite $m i$-clauses and infinitival (viz. $-r i$ ) clauses in subordinate contexts. ${ }^{10}$

In short, Loporcaro's analysis presupposes a Romance-internal development, according to which extension of erstwhile infinitival - $r i$ is driven by a system-internal symmetry to establish and transfer the distributional $p(a)$ pattern of the positive imperative to the corresponding cells of the negative imperative paradigm, viz. the $\mathrm{n}\left(\mathrm{c}_{2}\right)$ pattern. The role of contact is indirectly acknowledged in accounting for the lack of analogous extensions in other Romance varieties which exhibit the infinitive in the second person singular, insofar as these lack the mi-clauses/infinitive alternation which is only attested in these areas of historical Greek substrate. In the next section, however, we shall see on the basis of new data from a wider selection of southern Calabrian dialects that the role played by contact in this syntactic domain is more direct and is in fact the main trigger for the observed remodelling of the relevant paradigms.

\subsection{Cardeto and Gallicianò}

Our recent fieldwork investigations in southern Calabria confirm the extension of - $r i$ in Mosorrofa, but also reveal that the same pattern is attested in Cardeto and Gallicianò (province of Reggio Calabria). ${ }^{11}$ Significantly, however, our

10 For an overview and relevant bibliography, see Ledgeway (2016: 1018-1019, 1023-1027).

11 All examples from our own fieldwork appear unmarked, whereas examples from other sources are marked as such. In citing Romance data from our fieldwork we use a very 
TABLE 4 Imperative in Mosorrofa, Cardeto and Gallicianò Calabrian

\section{Mosorrofa, Cardeto, Gallicianò Calabrian Mosorrofa, Cardeto Gallicianò Calabrian}

\begin{tabular}{|c|c|c|c|c|c|c|}
\hline & Positive & Pat. & Negative & Pat. & Negative & Pat. \\
\hline $2 S G$ & $\begin{array}{l}=\text { IND. } 3 S G \\
(1 \text { conj. }) \\
=\text { IND. } 2 S G \\
(2 / 3 \text { conj. })\end{array}$ & $\mathrm{a}$ & $n o n+\mathrm{INF}-r i$ & $\mathrm{c}_{(1)}$ & $n o n+\mathrm{INF}-r i$ & $\mathrm{c}_{(2)}$ \\
\hline $3 S G$ & $m i+$ IND.3SG & b & $n o n+m i+\mathrm{IND} .3 \mathrm{SG}$ & & $n o n+m i+\mathrm{IND} .3 \mathrm{SG}$ & $\mathrm{b}$ \\
\hline 1PL & $=\mathrm{IND} .1 \mathrm{PL}$ & $\mathrm{a}$ & $n o n+I N D .1 P L$ & $a_{1}(d)$ & $\begin{array}{l}n o n+I N D .1 \mathrm{PL} \\
(+-r i)\end{array}$ & $\begin{array}{l}\mathrm{a}_{1} \\
\left(\mathrm{c}_{2}\right)\end{array}$ \\
\hline $2 \mathrm{PL}$ & $=\mathrm{IND} .2 \mathrm{PL}$ & $\mathrm{a}$ & $\begin{array}{l}n o n+\mathrm{IND} .2 \mathrm{PL} \\
(+-r i)\end{array}$ & $a_{1}\left(c_{1}\right)$ & $\begin{array}{l}\text { non+IND.2PL } \\
(+-r i)\end{array}$ & $\begin{array}{l}\mathrm{a}_{1} \\
\left(\mathrm{c}_{2}\right)\end{array}$ \\
\hline $3 \mathrm{PL}$ & $m i+\mathrm{IND} .3 \mathrm{PL}$ & $\mathrm{b}$ & $n o n+m i+\mathrm{IND} .3 \mathrm{PL}$ & & $n o n+m i+\mathrm{IND} .3 \mathrm{PL}$ & $\mathrm{b}$ \\
\hline
\end{tabular}

investigations bring to light for the Calabrian dialect of Gallicianò a paradigm for the negative imperative which, to date, has gone unnoticed. Specifically, in this dialect -ri extends optionally to the second person plural but never to the first person plural, witness the selection of examples in (7)-(9) (see also Ledgeway Schifano and Silvestri, in prep.: ch. 3). Table 4 offers an overview of the attested patterns.

(7) Positive (Mosorrofa, Cardeto, Gallicianò Calabrian) ${ }^{12}$
a. Danci
u libbru a
Mmaria! (Cardeto)
give.PRS.IND.3SG = DAT
the book to Maria
'Give Maria the book!' (2SG)

broad orthographic representation largely based on Italo-Romance practices. For the transliteration and transcription of Italo-Greek forms we adopt here, with some modifications, the relatively simple system used in Papageorgiadis (n.d.) in his adaptation of Karanastasis (1997). All examples taken from published sources are reproduced in their original orthographic form.

12 For the third persons, not attested in our corpus, we follow the literature, which reports the $m i$ + indicative pattern for southern Calabrese, e.g., Mi scrivi! 'let him write!' (Rohlfs, 1968: 355; cf. also Loporcaro, 1995). 
(7)
b. Cucinamu!
(Gallicianò Calabrian)
cook.PRS.IND.1PL
'Let's cook!'
c. Pighiattivillu u vinu russu! (Cardeto) take.PRS.IND.2PL=you.2PL=it.3SG the wine red 'Take the red wine!' (2PL)

(8) Negative (Gallicianò Calabrian) ${ }^{13}$
a. Non jiri a la casa!
NEG go.INF to the house
'Don't go home!' (2SG)
b. Non $n c i=\quad \operatorname{gridamu}\left({ }^{*} r i\right)$ !
NEG them.DAT $=$ shout.PRS.IND.1PL(.ri)
'Let's not shout at them!'
c. Non $n c i=\quad$ gridati(ri)!
NEG them.DAT $=$ shout.PRS.IND.2PL(.ri)
'Don't shout at them!' (2PL)
d. Li figghioli non mi toccanu nenti! the kids NEG that ${ }_{\text {IRREALIS }}$ touch.PRS.IND.3PL nothing 'Don't let the kids touch anything of mine!'

(9) Negative (Mosorrofa, Cardeto) $)^{14}$
a. Non $n c i=$ gridari $u$ figghiolu! (Mosorrofa)
NEG him.DAT = shout.INF the kid
'Don't shout at the kid!' (2SG)
b. Non jjimu me cattamu u pane! /
NEG go.PRS.IND.1PL that ${ }_{\text {IRREALIS }}$ buy.PRS.IND.1PL the bread non gridamuri! (Cardeto)
NEG shout.PRS.IND.1PL.ri
'Let's not go and buy the bread / let's not shout!' (2PL)

13 For the non $m i$ + indicative pattern of the third person singular in southern Calabrese, see Rohlfs (1968: 355), e.g., Num mi curri nuddu 'Nobody run!' (cf. also Loporcaro, 1995).

14 On the $m i$ + indicative pattern for the third person singular, our corpus includes examples from nearby localities, e.g., Non mi tocca nente! 'Don't let him/her touch anything of mine!' (Chorìo di Roghudi). 

c. Non $n c i=\quad$ gridatiri $u$ figghiolu! ${ }^{15}$ (Mosorrofa)
NEG him.DAT $=$ shout.PRS.IND.2PL.ri the kid
'Don't shout at the kid!' (2PL)
d. E figghioli non me gridanu! (Cardeto) the kids NEG that ${ }_{\text {IRREALIS }}$ shout.PRS.IND.3PL
'Don't let the kids shout (at me)!'

The facts for Gallicianò therefore call into question the validity of Loporcaro's original account based solely on the dialect of Mosorrofa. More specifically, if -ri extends from the second person singular to restore a two-pattern paradigm driven by the distributional symmetry of the mi/infinitive alternation exhibited in embedded contexts (viz. the $n\left(c_{2}\right)$ and $n(b)$ patterns: $2 S G, 1 / 2 P L$ vs. 3 SG / $\mathrm{PL})$, its failure to extend to the first person plural, as witnessed in Gallicianò, produces a system which still retains three patterns and where the mi/infinitive alternation is not wholly restored (viz. partial $n\left(a_{1}\right)$ pattern, (partial) $n\left(c_{(1)}\right)$ pattern and $\mathrm{n}(\mathrm{b})$ pattern: $1(/ 2)$ PL vs. 2SG(/PL) vs. 3SG/PL).

\section{Language Contact: Greko Sub-/Adstrate}

In light of our observations regarding the more nuanced distribution of the -ri morpheme alongside alternative patterns with $m i$, the diachronic processes by which this erstwhile infinitival ending was extended must be reconsidered. More specifically, we claim that the driving factor in the extension of - $r i$ is the role played by the underlying local Greek sub-/adstrate, viz. Greko, which is shared by all three of the villages exhibiting this phenomenon. Indeed, our parallel investigations in the surviving Greko-speaking villages in the province of Reggio Calabria, namely Bova, Chorio di Roghudi, Roghudi as well as Gallicianò itself, have brought to light a number of patterns in the imperative paradigm which, we argue, have played a role in shaping the observed Romance forms and their distributions.

We start by considering the paradigm for the positive imperative in Greko as reported in traditional sources (Falcone, 1973: 288; Rohlfs, 1977: 107-109;

15 Data reported in Loporcaro (1995: 348 , fn.36) show that -ri is always optional in Mosorrofa too. 
TABLE 5 Positive imperative in Greko

Positive imperative

\begin{tabular}{|c|c|c|}
\hline $2 S G$ & IMP (-e/-a, 1st/2nd conj.) & $\gamma$ \\
\hline 3 SG & $n a$ 'THAT ${ }_{\text {IRREALIS }}^{\prime}+\mathrm{SBJV}$ & $\beta$ \\
\hline 1PL & $=1 \mathrm{PL}$ IND & $\delta$ \\
\hline $2 \mathrm{PL}$ & IMP (-ete/-ate, 1st/2nd conj.) & $\gamma$ \\
\hline 3PL & $n a{ }^{\prime}$ THAT $_{\text {IRREALIS }}^{\prime}+\mathrm{SBJV}$ & $\beta$ \\
\hline
\end{tabular}

Katsoyannou, 1995: 324; Karanastasis, 1997: 82-83; Violi, 2004: 72), which is given in Table $5 \cdot^{16}$

We observe 3 distinct patterns. Pattern $(\gamma)$ characterizes the second person singular and plural where we find dedicated imperatival forms built on the erstwhile perfective stem followed by distinctive singular/plural person formatives, as illustrated in (10a-b). These, in turn, formally contrast with the corresponding (exhortative/jussive) subjunctive forms (11a-b), also built on the erstwhile perfective stem and introduced by the irrealis modal particle na (cf. southern Calabrian $m i$ above), and with the corresponding indicative forms built on the original imperfective stem $(12 \mathrm{a}-\mathrm{b}) .{ }^{17}$

a. Grázz-e!

(Bova; Rohlfs, 1977)

write.IMP.2SG

'Write!'

b. Grázz-ete!

write.IMP.2PL

'Write!'

(11)
a. $\quad N a$
grazz-i!
(Bova; Rohlfs, 1977)
that
write.SBJV.2SG
'(That) you should write!'
b. $\quad N a$
grázz-ite!
that
write.SBJV.2PL
'(That) you should write!'

16 For the first person plural, Karanastasis (1997: 83) reports the use of the subjunctive.

17 See Katsoyannou $(1995: 286,292)$ on an -ete variant for the second person plural form of the subjunctive (11b) and present indicative (12b). 

(12) a. Gráf-i $(s)(e) . \quad$ (Bova; Rohlfs, 1977) write.PRS.IND.2SG
'You write.'
b. Gráf-ite.
write.PRS.IND.2PL
'You write.'

The second pattern $(\beta)$ is suppletive and is found with the third persons which employ the subjunctive (13a-b), a verb form based on the earstwhile perfective stem introduced by the modal irrealis particle $n a$ largely comparable to the third-person Romance forms introduced by mi reviewed above (cf. the $\mathrm{p}(\mathrm{b})$ pattern in Table 4).
a. $\quad N a$
cámi!
(Bova; Rohlfs, 1977: 109)
that do.SBJV.3SG
'Let him do it!'
b. $\quad N a$
cámusi!
that
do.SBJV.3PL
'Let them do it!'

The third and final pattern $(\delta)$ is unique to the first person plural which suppletively employs the corresponding present indicative form (14), albeit marked by distinct prosodic (viz. intonational) properties.
(14) Gráfome!
(Greko; Rohlfs, 1977: 109)
write.PRS.IND.1PL
'Let's write!'

As for the negative imperative, Rohlfs (1977: 193) reports for the second persons singular and plural the suppletive use of the subjunctive paradigm optionally introduced by the irrealis modal particle $n a$ but obligatorily marked by the distinctive irrealis negator mi (cf. realis negator $(d) e n$ ).
a. $M i$
písi!
(Greko; Rohlfs, 1977: 193)
NEG drink.SBJV.2SG
'Don't drink!'
b. $\quad M i$
klázzite!
NEG
'Don't cry!' cry.SBJV.2PL 


\begin{tabular}{|c|c|c|c|c|}
\hline & Positive & Pat. & Negative & Pat. \\
\hline $2 S G$ & $\operatorname{IMP}(-\mathrm{e} /-\mathrm{a})$ & $\gamma$ & $\left(n a^{\prime}\right.$ 'THAT $\left.\mathrm{IRREALIS}^{\prime}\right) m i^{\prime} \mathrm{NEG}^{\prime}+\mathrm{SBJV}$ & $\beta$ \\
\hline $3^{S G}$ & $n a$ 'THAT $_{\text {IRREALIS }}{ }^{\prime}+\mathrm{SBJV}$ & $\beta$ & ( $n a$ 'THAT IRREALIS $) m i$ 'NEG'+SBJV & $\beta$ \\
\hline \multirow[t]{2}{*}{ 1PL } & IND.1PL & $\delta$ & den 'NEG'+IND.1PL & $\delta$ \\
\hline & & & $\begin{array}{l}\left((i a) n a \text { '(for) THAT } \text { IRREALIS }^{\prime}\right) m i \text { 'NEG'+SBJV } \\
\text { den 'NEG' èkhome na 'have.IND.1PL THAT }{ }_{\text {IRREALIS }}^{\text {' }}+\text { SBJV }\end{array}$ & $\begin{array}{l}\beta \\
\varepsilon\end{array}$ \\
\hline $2 \mathrm{PL}$ & IMP (-ete/-ate) & $\gamma$ & $\left(n a^{\prime} \mathrm{THAT}_{\text {IRBEALIS }}^{\prime}\right) m i{ }^{\prime} \mathrm{NEG}^{\prime}+\mathrm{SBJV}$ & $\beta$ \\
\hline $3 P L$ & $n a a^{\prime} \mathrm{THAT}_{\text {IRREALIS }}+\mathrm{SBJV}$ & $\beta$ & 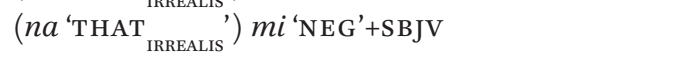 & $\beta$ \\
\hline
\end{tabular}

While our own recent investigations confirm the traditional picture reported above for the Greko positive imperative, the situation for the negative imperative proves more variable, as exemplified in (16)-(17) and summarised in Table 6.

(16) Positive $(\text { Greko })^{18}$
a. Kame
sirma! (Gallicianò)
do.IMP.2SG
quickly
'Hurry up!'
b. Kherònnome
na
kàmome
start.PRS.IND.1PL that ${ }_{\text {IRREALIS }}$ make.SBJV.1PL
to
faji!
(Chorìo di Roghudi)
the
food

'Let's start to prepare the food!'

c. Piateto

take.IMP.2PL=it

'Take this wine!' tundo krasi! (Bova)

this wine

(17) Negative (Greko)
a. $\mathrm{Na}$
mi
kuddise!
/ Mi platèssise
that ${ }_{\text {IRREALIS }}$
fitta!
NEG shout.SBJV.2SG NEG speak.SBJv.2SG
loudly
'Don't shout!' / 'Don't speak loudly!'

(Gallicianò)

18 For the third persons, not attested in our corpus, we follow the literature mentioned above, which reports the $n a$ + subjunctive pattern, e.g., Bovese Na kami! 'Let him/her do it!', $N a$ grázzusi! 'Let them write!' (Rohlfs, 1977: 107, 109). 
b. San

$$
\text { arrivespi } \quad \text { i Maria, mi }
$$

when

arrive.PRS.IND.3SG the Maria NEG

anji tipote!

(Chorìo di Roghudi)

touch.sBJv.3SG nothing

'When Maria arrives, don't let her touch anything!'

c. Den

kuddizome!

(Gallicianò)

NEG

shout.PRS.IND.1PL

'Let's not shout!'

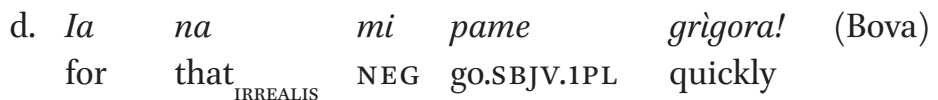

'Let's go not quickly!'

e. $\mathrm{Na} \quad \mathrm{mi}$ kuddime! (Gallicianò)

that ${ }_{\text {IRREALIS }}$ NEG shout.SBJV.1PL

'Let's not shout!'

f. Mi $t u=\quad$ kuddiome panta sta

NEG them.DAT $=$ shout.SBJV.1PL always to.the

pedia $=m a$ !

(Bova)

kids =our.GEN

'Let's not always shout at our kids!'

g. Den èkhome na tavrime

NEG have.PRS.IND.1PL that ${ }_{\text {IRREALIS }}$ beat.SBJV.1PL

tu pediu! (Gallicianò)

the.DAT kid.DAT

'Let's not hit the kid!' (lit. we do not have to hit the kid)

h. $\mathrm{Na} \quad \mathrm{mi} \quad$ kuddite! (Gallicianò) /

$\begin{array}{lll}\text { that } & \text { NEG } & \\ m i & \text { kndealis } & \text { (Chorio di Roghudi) }\end{array}$

NEG shout.SBJV.2PL

'Don't shout!'

i. An ertun ta pedia, mi

if come.PRS.IND.3PL the kids NEG

njiun tipote! (Gallicianò)

touch.SBJV.3PL nothing

'If the kids come, don't let them touch anything!' 
We thus see a general extension in the negative paradigm of suppletive pattern $p(\beta)$ consisting of the subjunctive (built on the erstwhile perfective stem) to all persons, indeed the only option outside of the first person plural. In the first person plural, however, we find as many as three different strategies: the $(\beta)$ pattern, including a variant in which the irrealis modal particle is reinforced by the preposition ia 'for' (cf. southern Calabrian pe mmi/pemmi 'for(.)sBJV.PRT', standard modern Greek $\gamma(\alpha \nu \alpha$ 'for SBJV.PRT'), the simple ( $\delta$ ) pattern in conjunction with the realis negator den, and finally pattern $(\varepsilon)$ involving the deontic modal $e k h o$ 'have' followed by a subjunctive clause (cf. the Italo-Romance Types D and E in Table 2). ${ }^{19}$

If we now compare the imperatival paradigms in Greko with the forms of the negative imperative in the Romance dialect of Gallicianò (viz. Gallicianò Calabrian) in Table 7 , we witness an interesting parallel. In particular, we note that in Gallicianò Calabrian the extension of -ri from the second person singular to the second person plural, but crucially not to the first person plural, viz. the $n\left(c_{1}\right)$ pattern, restores the underlying $p(\gamma)$ pattern of the Greko positive imperative where we see that just the second persons singular and plural share dedicated imperatival forms. Significantly, this distribution of dedicated imperatival forms limited to just the second persons singular and plural is not otherwise found in the local Romance varieties (cf. Table 4), but is robustly attested in Greko, the contact model language which we believe to have shaped this innovative Romance replica pattern $\mathrm{n}\left(\mathrm{c}_{1}\right) \cdot{ }^{20}$ Given these facts, it is our claim that it can hardly be coincidental that Greko was lost considerably earlier in Mosorrofa and Cardeto than in Gallicianò, where the language survives to the present day. In particular, we argue that the differential extension of - $r i$ within the negative imperative paradigm of the Calabrian dialects of Gallicianò (the $\mathrm{n}\left(\mathrm{c}_{1}\right)$ pattern in Tables 4 and 7 ) on the one hand, and Mosorrofa and Cardeto (the $\mathrm{n}\left(\mathrm{c}_{2}\right)$ pattern in Table 4) on the other, reflects the fact that in conservative Gallicianò, where

19 According to Karanastasis (1997: 85), the first person plural can be conveyed via different strategies also in the positive paradigm of medio-passive verbs in Greko.

20 One might still object that the Gallicianò Calabrian pattern can be more naturally interpreted as an endogenous, rather than an exogenous, change in which the extension of $-r i$ to the second person plural simply represents a natural, language-internal grouping of the second persons. However, if this were the case, then we must ask why this same natural endogenous extension is never attested in the thousands of other Italo-Romance dialects (nor Romansch, Daco-Romance or early langue d'oïl varieties) which also suppletively employ the infinitive in the second person singular negative imperative, but, rather, only in those dialects which are or have recently been in contact with Greko. 
TABLE 7 Imperative in Greko (all villages) and Gallicianò Calabrian (our corpus)

Greko

Gallicianò Calabrian

\begin{tabular}{|c|c|c|c|c|c|c|}
\hline & Positive & Pattern & Negative & Pattern & Negative & \\
\hline $2 S G$ & $\operatorname{IMP}(-e /-a)$ & $\gamma$ & (na) $m i+\mathrm{SBJV}$ & $\beta$ & $n o n+\mathrm{INF}-r i$ & $\mathrm{c}_{1}$ \\
\hline $3 S G$ & $n a+\mathrm{SBJV}$ & $\beta$ & (na) $m i+\mathrm{SBJV}$ & $\beta$ & $n o n+m i+\mathrm{IND} .3 \mathrm{SG}$ & $\mathrm{b}$ \\
\hline \multirow[t]{3}{*}{$1 \mathrm{PL}$} & IND.1PL & $\delta$ & den+IND.1PL & $\delta$ & non+IND.1PL & $d$ \\
\hline & & & $((i a) n a) m i+\mathrm{sBJV}$ & $\beta$ & & \\
\hline & & & den èkhome na & $\varepsilon$ & & \\
\hline $2 \mathrm{PL}$ & $\operatorname{IMP}(-e /-a)$ & $\gamma$ & (na) $m i+\mathrm{sBJV}$ & $\beta$ & $n o n+\mathrm{IND} .2 \mathrm{PL}+-r i$ & $\mathrm{c}_{1}$ \\
\hline $3 P L$ & $n a+\mathrm{SBJV}$ & $\beta$ & (na) $m i+\mathrm{sBJV}$ & $\beta$ & $n o n+m i+\mathrm{IND} .3 \mathrm{PL}$ & $\mathrm{b}$ \\
\hline
\end{tabular}

the underlying Greko pattern $\mathrm{p}(\gamma)$ (cf. Tables $\left.5^{-7}\right)$ is still present, - $r i$ is only extended to the second person plural, whereas in innovative Mosorrofa and Cardeto, where the Greko distributional model $\mathrm{p}(\gamma)$ is no longer observable, ${ }^{21}$-ri has been analogically extended to the first person plural. In turn, this produced, not by chance, a symmetrical distribution with the Romance (viz. Calabrian) positive imperative which also groups together second person singular, second person plural and first person plural within a single pattern (cf. the p(a) pattern in Tables 3 and 4$).{ }^{22}$ If this contact-induced analysis is correct, witness further the fact that there are crucially no varieties in which -ri extends to the first person plural but not to the second person plural, we are witnessing yet another case of what Rohlfs aptly called spirito greco, materia romanza whereby an original Greek PAT(tern) has been recreated through Romance MAT(erial) (cf. Matras and Sakel, 2007).

\section{$4 \quad$ Competition between -ri and $m i$}

Alongside the negative forms of the Romance imperative incorporating (the extension of) infinitival $-r i$ in the second persons singular and plural, as well

21 In Cardeto Greko was lost in the latter half of the nineteenth century (cf. Morosi, 1878: 1; Rohlfs, 1977: XIX n.9a; Martino, 1980: 7-8; Squillaci, 2017: 170 n.30). Similarly, in the census of 1861 Greko was reported still to be spoken among members of the community in Mosorrofa, though not as robustly as in Cardeto, before dying out before the end of the century (Martino, 1980: 6-7).

22 A cursory examination of the patterns described in Manzini and Savoia (2005: 388ff.) reveals the (synchronic) spreading of a suppletive form according to the hierarchy $2 \mathrm{SG}>2 \mathrm{PL}>1 \mathrm{PL}$ to be very common across Italo-Romance. 
as the first person plural in Mosorrofa and Cardeto, we also find competing formations with these same three persons involving the irrealis modal particle mi plus the present indicative (18a-c; cf. Rohlfs, 1968: 355; Ledgeway, 1998: 47), otherwise typical of the third persons (cf. the $\mathrm{p} / \mathrm{n}(\mathrm{b})$ patterns in Tables 3 and 4). ${ }^{23}$ The result is a Calabrian replication of the Greko pattern $\mathrm{n}(\beta)$ in Table 7 illustrated in Table 8.
a. Non
$m i$
$t i=$ permetti!
NEG
that ${ }_{\text {IRREALIS }}$
you $=$ permit.PRS.IND.2SG
(Mosorrofa)
'Don't you dare!'
b. Non mi nci= lu dicimu! (Gallicianò Calabrian) NEG that ${ }_{\text {IRREALIS }}$ him.DAT $=$ it.ACC $=$ say.PRS.IND.1PL
'Let's not tell him!'
c. Non mi nci= minati! (Gallicianò Calabrian)
NEG that ${ }_{\text {IRREALIS }}$ him.DAT= beat.PRS.IND.2PL
'Don't beat him!'

Notably, however, whenever these suppletive forms introduced by the irrealis modal particle are employed in the second persons singular and plural, as well as in the first person plural in Mosorrofa and Cardeto, they invariably prove incompatible with the extension of -ri, witness the representative second person plural examples in (19a-b).
(19) a. Non mi $\quad n c i=\quad \operatorname{minati}\left({ }^{*} \mathrm{ri}\right) ! \quad$ (Gallicianò Calabrian) NEG that him.DAT= beat.PRS.IND.2PL(.ri) 'Don't hit him!'

$\begin{array}{lll}\text { b. Non } & n c i= & \text { minati(ri)! } \\ \text { NEG } & \text { him.DAT }= & \text { beat.PRS.IND.2PL(.ri) }\end{array}$

'Don't hit him!'

23 The preverbal negation and the irrealis modal particle are often represented orthographically as a single univerbated form, namely (variants of) nommi and, in some Calabrian varieties, also dommi (cf. example (i) in fn.9). 
Greko
Southern Calabrian

Pattern Negative

Pattern

\begin{tabular}{|c|c|c|c|}
\hline \multirow{2}{*}{$2 S G\left(n a\right.$ 'THAT $\left.{ }_{\text {IRREALIS }}^{\prime}\right) m i$ 'NEG'+SBJV } & $\beta$ & $n o n+m i+\mathrm{IND}$ & b \\
\hline & & $n o n+\mathrm{INF}-r i$ & $\mathrm{c}_{(1(, 2))}$ \\
\hline 3SG (na 'THAT_' $\left.{ }^{\prime}\right) m i$ 'NEG'+SBJV & $\beta$ & $n o n+m i+\mathrm{IND}$ & $\mathrm{b}^{\prime}$ \\
\hline $1 \mathrm{PL}\left((i a) n a^{\prime}\right.$ (for) THAT $\left.\mathrm{THREALIS}^{\prime}\right) m i^{\prime} \mathrm{NEG}^{\prime}+\mathrm{SBJV}$ & $\beta$ & $n o n+m i+\mathrm{IND}$ & $\mathrm{b}$ \\
\hline den 'NEG' + IND.1PL & $\delta$ & non+IND.1PL & $a_{1}(d)$ \\
\hline den 'NEG' èkhome na 'have.IND.1PL'+SBJV & $\varepsilon$ & $n o n+$ IND.1PL-ri & $\mathrm{c}_{2}$ \\
\hline $2 \mathrm{PL}\left(n a^{\prime}\right.$ THAT $\left._{\text {IRREALIS }}^{\prime}\right) m i i^{\prime} \mathrm{NEG}^{\prime}+\mathrm{SBJV}$ & $\beta$ & $n o n+m i+\mathrm{IND}$ & $\mathrm{b}$ \\
\hline & & non+IND.2PL & $a_{1}$ \\
\hline & & $n o n+\mathrm{IND} .2 \mathrm{PL}+-r i$ & $c_{1}$ \\
\hline 3PL $\left(n a^{\prime}\right.$ 'THAT $\left.{ }_{\text {IRREALIS }}^{\prime}\right) m i{ }^{\prime} \mathrm{NEG}^{\prime}+\mathrm{SBJV}$ & $\beta$ & $n o n+m i+\mathrm{IND}$ & $\mathrm{b}$ \\
\hline
\end{tabular}

It is natural then to ask why -ri has not been extended to examples such as (19a) if, as we have argued in Section 3, -ri is extended in conjunction with non $+2 \mathrm{PL}$ indicative to restore an underlying Greko formal distribution (viz. the $\mathrm{p}(\gamma)$ pattern in Table 7 ), and then subsequently extended by analogy to the first person plural in Mosorrofa and Cardeto following the loss of Greko in these two localities in line with the $\mathrm{p}(\mathrm{a})$ pattern in Table 4. The answer, we argue, lies in the functional structure and licensing of imperatival clauses. Specifically, we adopt here the idea widespread in the literature (Rivero, 1994a; 1994b; Graffi, 1996; Zanuttini, 1997; Manzini and Savoia, 2005: 388) that imperatival clauses display a reduced functional structure. In particular, while declaratives are standardly argued to project a full array of functional projections associated with the T-domain (20a), imperatival clauses (2ob) are assumed to lack this same series of functional projections (cf. also Tortora, 2014: ch.3, Section 6). Not by chance, the absence of T-related functional projections in (second-person singular) imperatival clauses is correlated with the frequent traditional observation that one of the most notable characteristics of the imperative is its absence of any inflexional marking or, at the very least, very minimal inflexional marking in accordance with a widespread cross-linguistic tendency (Bybee, 1985: 173; Floricic, 2008: 10; Ledgeway, 2014). Theoretically, we can interpret the observed inflexional impoverishment of the imperative in terms of the mechanisms of feature transmission and inheritance (Chomsky, 2007; 2008): whereas phi-features that originate on the phase head, viz. $\mathrm{C}^{\circ}$, are usually 'transferred' down to $\mathrm{T}^{\circ}$ in root declaratives, in the absence of $\mathrm{T}^{\circ}$ 
and related functional structure in imperatives these same features fail to be passed down - or, to borrow Ouali's (2008) terminology are 'kept' - such that the imperatival verb is forced to raise to $\mathrm{C}^{\circ}$ to license its inflexional features (Rivero, 1994a; 1994b; Rivero and Terzi, 1995; Manzini and Savoia, 2005: 388). As a consequence, any clitics are stranded in situ within the $v$-VP complex from where they subsequently encliticize, not syntactically, but phonologically at PF to the imperatival verb now raised to $\mathrm{C}^{\circ}$.

(20) a. $\left[_{\mathrm{TP}}\right.$ Gli= avete $\quad\left[_{\nu-\mathrm{VP}}\right.$ servito la cena. $\left.]\right]$ (Italian) him.DAT $=$ have.PRS.IND.2PL serve.PTCP the dinner

'You have served him dinner.'

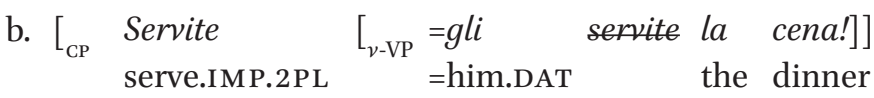
'Serve him dinner!'

In negative imperatives, by contrast, the presence of the sentential negator instantiates a functional head whose presence in the clause necessarily forces the projection of the T-domain, otherwise absent in positive imperatives. As a consequence, negative imperatival clauses are therefore predicted to be inflexionally richer than affirmative imperatival clauses since they automatically come with T-related functional positions to host the inflected verb and any accompanying clitics, as exemplified by the Italian example in (21).

$\begin{array}{lllll}\text { (21) }\left[_{\mathrm{CP}} \ldots\left[_{\mathrm{TP}}\right.\right. & \text { Non la } & \text { la } & \text { servite } \\ & \text { NEG } & \text { it.ACC }= & \text { serve.IMP.2PL }\end{array}\left[_{\nu-\mathrm{VP}}\right.$ la=servite! $\left.\left.]\right]\right]$ (Italian) 'Don't serve it!'

Further direct proof of this analysis can be seen in numerous Italian dialects (cf. Type D in Table 2) where, in contrast to the positive imperative, the $\mathrm{T}^{\circ}$ head is exceptionally lexicalized in the negative imperative through an overt auxiliary, a reflex of STARE 'stand' (22a), selecting an infinitival complement (Zanuttini, 1994; 1997:150-54; Manzini and Savoia, 2005: Section 7.2; Ledgeway, 2019). It is logical therefore to assume that so-called suppletive cases of the simple infinitive such as Italian (22b) employed in the second person singular negative imperative (cf. the $\mathrm{n}(\mathrm{c})$ pattern in Tables 3 and 4) simply involve a null auxiliary (Kayne, 1992; Portner and Zanuttini, 2003; Zanuttini, 1994; 1997: 118ff.). 
(22) a. $\left[_{\mathrm{TP}}\right.$ non stá $\quad{ }_{v \text {-VP }}$ parlare! $\left.]\right]$ (Padua; Zanuttini, 1997:119) NEG stand.PRS.IND.2SG speak.INF

'Don't speak!'

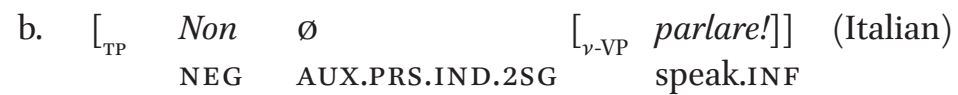

'Don't speak!'

In the light of this evidence, we can conclude that extension of the infinitival marker -ri in the relevant dialects of southern Calabria to the second person plural (23c) and, in Mosorrofa and Cardeto, to the first person plural (23b), implies its selection by a null auxiliary in TP along the lines of the second person singular (23a). Consequently, forms such as parrati-ri and parra$m u$-ri which are selected by a null auxiliary must be reanalysed as inflected infinitives, in contrast to the original competing forms without -ri (viz. parrati, parramu) which, in the absence of a null auxiliary, involve V-raising to the T-domain (23d-e).

$$
\begin{aligned}
& \text { a. } \left.\left.]_{\mathrm{TP}} \text { Non } \varnothing \quad{ }_{\nu \text {-VP }} \text { parrari! }\right]\right] \text { (sth. Calabrian) } \\
& \text { NEG AUX.PRS.IND.2SG speak.INF } \\
& \text { b. }\left[_{\mathrm{TP}} \text { Non } \varnothing \quad\left[{ }_{\nu \text {-VP }} \text { parramuri! }\right]\right] \text { (sth. Calabrian) } \\
& \text { NEG AUX.PRS.IND.1PL speak.INF.1PL } \\
& \text { c. } \left.]_{\mathrm{TP}} \text { Non } \varnothing \quad\left[{ }_{\nu \text {-VP }} \text { parratiri! }\right]\right] \text { (sth. Calabrian) } \\
& \text { NEG AUX.PRS.IND.2PL speak.INF.2PL } \\
& \begin{array}{lll}
\text { d. } \quad\left[\begin{array}{l}
\text { NP } \\
\text { NEG }
\end{array}\right. & \text { sparramu } \left.\left[_{\nu \text {-VP }} \text { parramu! }\right]\right] \text { (sth. Calabrian) } \\
&
\end{array} \\
& \text { e. }\left[_{\mathrm{TP}} \text { Non parrati }{ }_{\nu \text {-VP }} \text { parrati! }\right] \text { (sth. Calabrian) } \\
& \text { NEG speak.PRS.IND.2PL }
\end{aligned}
$$

Note that there is an important structural difference between this southern Calabrian example of an inflected infinitive and the well-known standard cases of the inflected infinitive reported for other Romance varieties such as Portuguese, Galician, old Leonese, central-northern Sardinian, and old Neapolitan (for an overview and references, see Ledgeway, 2012: 293-294). In the former case, the infinitival marker is the outermost morpheme following the person/number marker (cf. parra-mu-ri 'speak-AGR.1PL-INF'), whereas 
in the latter the person/number marker is attached to the infinitival marker which is, in turn, suffixed to the verb stem (cf. Portuguese fala-r-mos 'speakINF-AGR.1PL'). These internal structural differences clearly relate to the very distinct paths by which these forms arose, namely adjunction of infinitival - $r i$ to a present indicative verb form (viz. parramu > parramu+-ri > parramuri) vs. reanalysis of the Latin imperfective subjunctive (Ibero-Romance, Sardinian: *FABULAREMUS > Portuguese falarmos; cf. Maurer, 1968; Jones, 1992; 1993: 7882) or pluperfect indicative ( ${ }^{*}$ PARABOLA(UE)RAMUS > Old Neapolitan par$\operatorname{lar}(e) m(m) o$; cf. Loporcaro, 1986).

Returning to the incompatibility of -ri with the competing negative imperatival forms introduced by the irrealis modal particle $m i$ (cf. 19a and the $\mathrm{n}(\mathrm{b}$ ) pattern in Table 8), we now have a principled explanation for this observation. Assuming with Ledgeway (1998; 2007; 2013: 4 n.9) and Damonte (2010) that Calabrian $m i$ is a T-element, its incompatibility with infinitival -ri follows without further stipulation since mi would be competing for the same T-position as the null auxiliary required to license infinitival -ri. The complementary distribution of $m i$ and the extension of infinitival - $r$ i illustrated in (24a-b) therefore falls out naturally. ${ }^{24}$

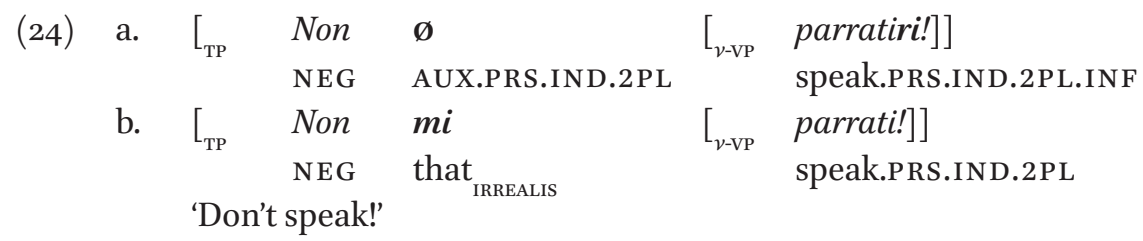

\section{$5 \quad$ Extension of -ri: a Hybrid Pattern?}

In view of the contact-induced developments and associated distributional patterns considered above, it is now time to return to the distinction between true and suppletive imperatives introduced at the outset of this article. Above we noted following Zanuttini (1997: 105) that true imperatives involve "verbal forms that are unique to the paradigm of the imperative, in the sense that they are different from any other verbal form used for the same person in any other verbal paradigm." Given this definition, we are led to conclude that extension of - $r$ i from the second person singular to the second (and first) person(s) plural

24 There are at least two other possible competing explanations for the observed incompatibility of -ri with $m i$-forms of the negative imperative. One, a functional-based approach, would 
TABLE $9 M i$ - and -ri patterns in Mosorrofa, Cardeto, Gallicianò Calabrian

\begin{tabular}{|c|c|c|c|c|}
\hline & Grammar A & Pattern & Grammar B & Pattern \\
\hline $2 S G$ & $n o n+\mathrm{INF}-r i$ & $\mathrm{~g}_{(1(2))}$ & $n o n m i+I N D$ & $\mathrm{~b}$ \\
\hline $3 S G$ & $n o n m i+$ IND & $\mathrm{b}$ & $n o n m i+$ IND & $\mathrm{b}$ \\
\hline $1 \mathrm{PL}$ & $n o n+\operatorname{IND}(+-r i)$ & $\mathrm{a}\left(\mathrm{g}_{2}\right)$ & $n o n m i+$ IND & $\mathrm{b}$ \\
\hline $2 \mathrm{PL}$ & $n o n+\operatorname{IND}(+-r i)$ & $a\left(g_{1}\right)$ & non $m i+$ IND & $\mathrm{b}$ \\
\hline $3 P L$ & $n o n m i+$ IND & $\mathrm{b}$ & $n o n m i+\mathrm{IND}$ & $\mathrm{b}$ \\
\hline
\end{tabular}

as part of the emergence of an $\mathrm{n}\left(\mathrm{c}_{(1 / 2))}\right)$ pattern gives rise to the concomitant genesis of novel true negative imperatives, as schematized in Table 10.

Whereas the use of the Romance infinitive in the second person singular negative imperative is standardly interpreted as suppletive (cf. Type B in Table 2), ${ }^{25}$ it is highly questionable whether this analysis is still applicable for

be to argue, following Ledgeway (1998: Section 7), that synchronically southern Calabrian $m i$-clauses behave and should be analysed as inflected infinitival clauses in which proclitic $m i$, just like the infinitival suffix - RE (> southern Calabrian -ri) also licensed under $\mathrm{T}^{\mathrm{o}}$ (i.a; cf. Kayne, 1991), functions as an infinitival marker generated under $\mathrm{T}^{\mathrm{o}}$ in conjunction with a verb inflected for person and number (i.b).

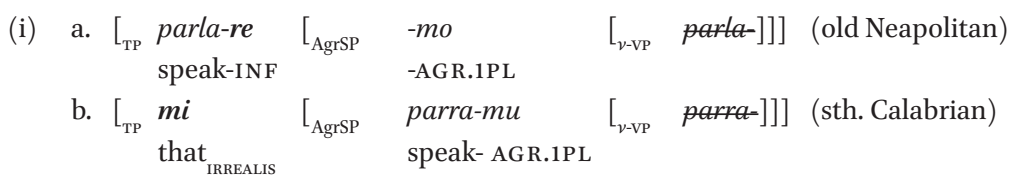

Given the functional and structural equivalence between proclitic $m i$ and suffixal -RE (>-ri), both analysed as infinitival T-markers, $m i$ is predicted to be incompatible with the extension of an additional infinitival marker. Another approach would be to view the mi-pattern and ri-pattern as the outputs of two originally distinct grammars, as in Table 9. We have seen above that in Grammar A extension of -ri to just the second person plural (and subsequently in Mosorrofa and Cardeto also to the first person plural) is driven by contact-induced internal pressure to restore the distributional pattern of the underlying Greko positive imperative (cf. the $\mathrm{p}(\gamma)$ pattern in Tables 5 and 6), hence its exclusion from the (first person plural and) third persons displaying $m i$-forms. In Grammar B, by contrast, the negative imperative is built on mi-forms in all persons (cf. 18a-c) in replication of the Greko negative imperative $\mathrm{n}(\beta)$ pattern in Tables 6 and 7 . The infinitive then has no foothold in the negative imperative paradigm of Grammar B, not even in the second person singular, from which infinitival -ri could extend its distribution to come into contact with mi-forms.

25 Recall that the use of the infinitive in the second person singular negative imperative represents a suppletive use, since the infinitive may equally mark the second person singular (as well as all other persons) in embedded contexts as the complement to raising and control predicates. 
TABLE 10 Summary of Greko and southern Calabrian imperative paradigms

\begin{tabular}{|c|c|c|c|c|c|c|}
\hline & \multicolumn{2}{|c|}{ Greko } & \multicolumn{2}{|c|}{ Gallicianò Calabrian } & \multicolumn{2}{|c|}{ Mosorrofa/Cardeto } \\
\hline & Positive & Negative & Positive & Negative & Positive & Negative \\
\hline $2 S G$ & true & suppletive & true & suppletive $>$ true & true & suppletive $>$ true \\
\hline $3 \mathrm{SG}$ & suppletive & suppletive & suppletiv & suppletive & suppletiv & suppletive \\
\hline 1PL & suppletive & suppletive & suppletiv & suppletive & suppletiv & true \\
\hline $2 \mathrm{PL}$ & true & suppletive & suppletiv & true & suppletiv & true \\
\hline $3 \mathrm{PL}$ & suppletive & suppletive & suppletiv & suppletive & suppletiv & suppletive \\
\hline
\end{tabular}

many, if not all, southern Calabrian dialects. In the dialects of this area there is an ongoing and now highly advanced retreat of the infinitive (cf. Ledgeway, 2013: 4, 17-18; 2016: 1024-1025; Squillaci, 2017: chs 4,5; Ledgeway, Schifano and Silvestri, in prep.) such that its use as an embedded verb form is now, at best, a residual syntactic feature limited to the complement of a dwindling handful of functional predicates (essentially CAN; cf. Romanian), ${ }^{26}$ all of which now overwhelmingly select a so-called finite $m i$-clause. The result is that synchronically this verb form is now predominantly, if not wholly in the speech of many speakers, no longer to be considered functionally an infinitive since its distribution is now almost exclusively restricted to the second person singular negative imperative. Given this loss of its subordination uses and its increasing restriction to the second person singular negative imperative, the output of an ongoing and well-advanced process of refunctionalization (cf. Smith, 2005; 2011), it is natural to reinterpret the erstwhile infinitive as having shifted from suppletive (25a) to true (25b) imperative in the Romance negative paradigms of Table 10.

$\begin{array}{llll} & \text { Non } & \text { parra-ri! } & \text { (Mosorrofa) } \\ \text { a. } & \text { NEG } & \text { speak-INF } & \text { (suppletive) } \\ \text { b. } & \text { NEG } & \text { speak-IMP(.2SG) } & \text { (true) } \\ & \text { 'Don't speak!' } & & \end{array}$

By the same token, the extension of -rito the second person plural (26a) and, in turn, to the first person plural (27a) through the emergence of the $n\left(c_{1 / / 2)}\right)$ pattern further reinforces and extends this novel 'true' negative imperative

26 Indeed, this presumably explains the exceptional persistence of the infinitive in the second person singular negative imperative where, as argued in Section 4 (cf. 23a), it is selected by a null auxiliary. 
pattern $(26 \mathrm{~b}, 27 \mathrm{~b})$, inasmuch as the distribution of all the relevant $-r i$ forms is unique to the paradigm of the negative imperative.
Non
parramu-ri!
(Mosorrofa)
a. NEG
speak.PRS.IND.1PL-ri
b. NEG
speak.IMP.1PL
'Let's not speak!'

$\begin{array}{lll} & \text { Non } & \text { parrati-ri! } \\ \text { a. } & \text { NEG } & \text { speak.PRS.IND.2PL-ri } \\ \text { b. } & \text { NEG } & \text { speak.IMP.2PL } \\ & \text { 'Don't speak!' } & \end{array}$

(Mosorrofa)

Also relevant here is the striking parallel found in old Romanian. Following Mării (1969) and Zamfir (2005; 2007), Maiden et al. (forthcoming: Section 6.3.4) observe how in sixteenth- and seventeenth-century Romanian the 'long' form of the infinitive in -re used to mark the second-person singular imperative (28a), ${ }^{27}$ alongside the short form of the infinitive still used today (28b), is extended to mark the second-person plural with concomitant adjunction of the second-person plural marker $-t ̦ i(29 b)$, alongside the older suppletive second-person present indicative form (29a) still in use today. Differently from the southern Calabrian case where the erstwhile infinitival suffix $-r i$ is extended to the second-person plural present indicative form (viz. nu parrati $>$ nu parratiri), in old Romanian we see an extension of the entire infinitival form, not just the infinitival suffix, to the second person plural to which the distinct second-person plural marker is then added. In this respect, the internal structure of the old Romanian relevant form resembles the canonical forms of the inflected infinitive considered above (cf. Pt.fala-r-des 'speak-INF-2PL'). However, the southern Calabrian and old Romanian cases come together in several key respects: i) they both involve the genesis of a novel second-person plural 'true' imperative through extension of the infinitival suffix or the infinitive; ii) extension (initially) excludes the first-person plural (which is distinctly marked in (old) Romanian suppletively by a preverbal irrealis modal marker along the lines of the $\mathrm{n} / \mathrm{p}(\mathrm{b})$ pattern), bringing together the second persons singular and plural to restore an already existing distributional pattern (cf. $n u$ cântà!: nu cântàți!' vs. nu cântàre!: nu cântàreți!); and iii) on a par with southern

27 Although not used in official orthography, in the examples below we use a grave accent to indicate stress placement for expository purposes. 
Calabrian, (old) Romanian is characterized by a heavily reduced use of the subordinating uses of the infinitive which is increasingly restricted to just the second-person singular negative imperative, a necessary step for the reanalysis of the suppletive use of the infinitive as an innovative true imperative.

\begin{tabular}{|c|c|c|}
\hline a. & $\mathrm{Nu}$ & cânt-àre! \\
\hline & NEG & sing-INF \\
\hline & $\mathrm{Nu}$ & cântà! \\
\hline & NEG & sing.INF \\
\hline
\end{tabular}

\begin{tabular}{|c|c|c|}
\hline a. & $\mathrm{Nu}$ & cântàți!! \\
\hline & NEG & sing.PRS.IND.2PL \\
\hline b. & $\mathrm{Nu}$ & cântàre-ți! \\
\hline & NEG & sing.INF-2PL \\
\hline & 'Don' & \\
\hline
\end{tabular}

Significantly, then, we see that, although the infinitive suppletively marks the second-person singular negative imperative in thousands of (especially Italo-) Romance varieties, it is only extended in those varieties where the subordinating uses of the infinitive are radically attrited - under language contact with Greko in the case of southern Calabrian, and under language contact with other varieties of the Balkan Sprachbund (cf. Joseph, 1983; 2010; Friedman, 2006; 2011; Tomić, 2006; Friedman and Joseph, 2017; 2021; Krapova and Joseph, 2019, a.o.; see also Gardani et al., 2021) and, in particular, Greek in the case of Romanian -, such that infinitival morphology is free to be exaptively reinterpreted as a 'true', dedicated imperatival marker and from there extended to the second-person plural according to an already salient (language-internal or -external) paradigmatic distribution. We thus see that a so-called typical Balkanism has independently undergone a very similar development in two areas - southern Calabria and Romania - which have not otherwise been in contact with each other. This, in turn, underlines how so-called original Balkanisms can give rise, through time, to new "second-generation" Balkanisms, both within and outside the Balkan Sprachbund proper, thereby further reinforcing the linguistic cohesion of such varieties.

Within a wider Romance typology, the resulting opposition between true and suppletive imperatives in southern Calabrian (and now also in old Romanian) presents us with a unique distribution not previously recorded for Romance (cf. Table 1), as illustrated in Table 11. Table 11 presents all the logical combinations of true and suppletive forms for the Romance positive and 
negative imperative. Type (i) is found in varieties such as Piedmontese (30) which presents, at least for the $2 \mathrm{SG}$, a true imperatival form - indeed the same distinctive form - in both the positive and negative paradigms, an apparent counterexample to the so-called negative imperative puzzle. Type (ii), by contrast, shows a formal opposition between the positive and negative paradigms through the alternation between true and suppletive forms, respectively, where the latter can be an infinitive as in Italian (31b) or a subjunctive as in Gascon (32b).

(30) a. Parla! (positive, true) (Piedmontese; Zanuttini, 1997: 111) speak.IMP.2SG

'Speak!'

b. Parla nen! (negative, true) speak.IMP.2SG NEG

'Don't speak!'

a. Parla! (positive, true) (Italian)

speak.IMP.2SG

'Speak!'

b. Non

NEG

parlare! (negative, suppletive)

'Don't speak!'

(32) a. Cante! (positive, true) (Béarnais Gascon; Puyau, 2013: 91-92) speak.IMP.2SG

'Sing!'

$\begin{array}{llll}\text { b. } & \text { Ne } \quad \text { càntes } & \text { pas! } & \text { (negative, suppletive) } \\ \text { NEG } & \text { sing.PRs.sBJV.2SG } & \text { NEG } & \\ \text { 'Don't sing!' } & & \end{array}$ speak.INF

TABLE 11 Combinations of true/suppletive forms in Romance positive/negative imperative

\begin{tabular}{llll}
\hline & Positive & Negative & Example \\
\hline (i) & true & true & Piedmontese $(30)$ \\
(ii) & true & suppletive & Italian $(31)$, Gascon $\left(3^{2}\right)$ \\
(iii) & suppletive & suppletive & Catalan $(33)$, Venetan $(34)$ \\
(iv) & suppletive & true & $?$ \\
\hline
\end{tabular}


The remaining two combinations in Table 11 both involve a suppletive paradigm in the positive imperative. In type (iii), the suppletive positive imperative combines with a suppletive paradigm in the negative which can either be the same as that of the positive imperative as in Catalan (33a-b) or distinct as in Venetan (34a-b).

(33) a. Parleu! (positive, suppletive) (Catalan; Zanuttini, 1997: 109) speak.PRS.IND.2PL 'Speak!'
b. No
parleu!
(negative, suppletive)
'Don't speak!'

(34) a. t $t a^{\prime} m \varepsilon i=l u$ (positive, suppletive) (Calizzano; Manzini and Savoia, 2005: 451) speak.PRS.IND.2PL=him 'Call him!'
b. $n \varepsilon$
$s^{\prime} t \varepsilon i=l u$
tfa'ms
(negative, suppletive)
NEG
stand.PRS.IND.2PL=him
call.INF
'Don't call him!'

However, the fourth and final logical combination (iv), which marries together a suppletive positive paradigm with a true negative paradigm, has until now remained merely a theoretical possibility. Given, however, our hypothesis about the creation of novel true negative imperatives in southern Calabrian (Mosorrofa, Cardeto, Gallicianò Calabrian) as a concomitant of the contact-induced (almost complete) loss of subordinating uses of the infinitive and the extension of $-r i$, the empirical gap predicted by the typology presented in Table 11 can now be filled with the southern Calabrian second (and first) person(s) plural (35), as well as the old Romanian case noted by Maiden et al. (forthcoming) reviewed above (cf. 28-29).

(35) a. Parrati! I Parramu! (positive, suppletive) (sth. Calabrian) speak.PRS.IND.2PL speak.PRS.IND.1PL 'Speak! / Let's speak!'

b. Non parratiril parramuri! (negative, true)

NEG speak.IMP.2PL / speak.IMP.2PL

'Don't speak / let's not speak!' 
The significance of the southern Calabrian (and old Romanian) data in confirming the predicted combination (iv) of Table 11 fills not only a Romance gap, but is also of wider typological significance. In particular, a combined examination of WALS maps 70A (The Morphological Imperative; cf. Auwera, Lejeune, Pappuswamy, and Goussev, 2013) and $71 \mathrm{~A}$ (The Prohibitive; cf. Auwera, Lejeune and Goussev, 2005; Auwera, 2010) - see http://wals.info/combinations/70A_ $71 \mathrm{~A} \# 5 /-18.771 / 304.080$ - shows that the combination (iv) found in southern Calabrian is indeed typologically extremely rare. For the value 'no second person imperative', map 70A reveals that 122 out of 547 languages do not display morphologically dedicated second-person positive imperatives at all ( $\Rightarrow$ suppletive positive imperative), whereas the value 'special imperative + normal negative' for map $71 \mathrm{~A}$ reveals that out of 495 languages there are just 55 languages where the negative imperative uses a verbal construction different than the positive imperative whilst maintaining the same negative marker as in declaratives ( $\Rightarrow$ true or suppletive negative imperative). If we then compare and combine the results for both values from both maps, we can isolate through map $71 \mathrm{~A}$ languages where the negative imperative is distinct from the positive imperative and then cross-reference this group of languages against just those languages in map $70 \mathrm{~A}$ where the positive paradigm is suppletive, such that the negative imperative in the same varieties must either be true or suppletive, but in any case distinct from the positive imperative. This yields just three possible languages out of a total of 474, namely Gooniyandi (Australia), Svan (Georgia) and Trumai (Brazil), ${ }^{28}$ which, on a par with southern Calabrian, potentially combine suppletive and true forms in the positive and negative paradigms of the imperative, respectively.

However, a closer look at the relevant descriptions shows that in both Gooniyandi (McGregory, 1990: 542-543) and Svan (Tuite, 1997: 42; 2018: 61) the negative imperative is suppletive, and not true: in the former the verb assumes the present definite form and in the latter either the present or future indicative (when introduced by the negator nom) or the optative or conjunctive (when introduced by the negator nosa). The picture in Trumai proves more complex where the verb shows very little morphology, with relevant grammatical categories mainly expressed by accompanying particles or auxiliaries (Monod-Becquelin, 1975: 98). Indeed, the imperative is variously marked by the particles wana, waki, wa and wanach (Monod-Becquelin, 1975: Section 3.4), the distribution of which is determined by polarity, transitivity and the animacy of the Patient argument $(\mathrm{O})$. In the positive imperative the uninflected verb

28 If we include the combination 'special negative + special imperative' in map 71A, we obtain a further 15 possible languages, which is still a considerably reduced sample. 
is preceded by wana with intransitives, and by wa and waki with transitives in accordance with the animacy or otherwise of the O, respectively (MonodBecquelin, 1975: 111, 250). In the negative imperative, by contrast, the relevant particles must now all follow the verb, namely wanach with intransitives and waki with transitives (Monod-Becquelin, 1975: 113-112, 251-252). We see therefore that a formal distinction between true and suppletive imperatives is harder to recognise in this case, since there is some overlap in the distribution of the positive and negative particles, e.g., transitive waki and potentially also positive intransitive wana if related to negative intransitive wanach. Syntactically, however, there is a sharp distinction between the preverbal and postverbal positions of the positive and negative imperatival particles. The overall picture is therefore inconclusive in several respects: (i) the positive imperative can hardly be described as 'suppletive', in that the uninflected verb is marked off by distinct preverbal particles; (ii) the negative imperative can hardly be described as 'true', in that there is some formal overlap in the distribution of imperatival particles in positive and negative imperatives; and (iii) the distinction between positive and negative imperatives is robustly marked by the respective preverbal vs. postverbal position of the particle.

Consequently, we tentatively conclude that the dialects of Gallicianò, Mosorrofa and Cardeto, together with old Romanian, constitute to date the only secure examples of combination (iv) in Table 11, an otherwise unattested option, the exceptional presence of which in southern Calabria can plausibly be explained as the hybrid outcome of contact between indigenous Greek and Romance grammars.

\section{Conclusions and Summary}

The data discussed in this article have shown how language contact between indigenous Greek (viz. Greko) and Romance (viz. southern Calabrian) grammars has led to the creation of a hybrid Romance negative imperative paradigm which marries together traditional finite verb forms (marked for person and number) with an erstwhile infinitival ending. At the basis of this paradigm is a Greek ad-/substrate model where the distinctive marking of the second persons singular and plural in the positive imperative is transferred to the southern Calabrian negative imperative through the extension of the infinitival ending -ri from the second person singular to the second person plural and, in turn, by analogy to the first person plural in Mosorrofa and Cardeto. 
The synchronic contrast in the extension of -ri in Gallicianò Calabrian (2SG $>2 \mathrm{PL})$ on the one hand and in Mosorrofa and Cardeto (2SG > 2PL > 1PL) on the other effectively rules out a Romance-internal motivation for the original 2SG > 2PL stage but, rather, points to a contact-induced change where Romance MAT(erial) has reproduced a Greek PAT(tern) in line with Rohlfs' common mantra spirito greco, materia romanza (for discussion, see Ledgeway, 2006; 2013; and Ledgeway, Schifano and Silvestri, in prep. on Greek-Romance contact, see also Ralli, 2021).

As is often the case in situations of language contact, the particular changes affecting the southern Calabrian paradigm of the negative imperative give rise to typologically non-linear and exceptional developments which ultimately distort the expected and regular Romance 'type'. Here we have seen two key examples. Firstly, we have observed how the extension of infinitival -ri, first to the second person plural under the influence of a Greek distributional model and then, in Mosorrofa and Cardeto, under the influence of a Romance model to the first person plural, leads formally to the creation of apparently new inflected infinitival forms. Secondly, we are forced to recognise in these same innovative inflected infinitival forms, including the bare infinitive in the second person singular following the almost complete loss of its subordinating functions, the emergence of a novel 'true' paradigm for the negative imperative since all the relevant forms are unique to the negative imperative. At the same time, the emergence of this novel paradigm also brings about an otherwise extremely rare typological opposition between suppletive and true forms in the positive and negative paradigms of the imperative, respectively, which is otherwise only found in a specific period of old Romanian. Once again, we see that this rare typological pattern is not the output of a linear Romance-internal development, but, rather, the consequence of language contact between Greek and Romance grammars, the resolution of which leads to this otherwise typologically extremely rare, but logically predicted, distribution of true and suppletive forms.

Finally, in the present article we have shown that, although the infinitive is suppletively employed to mark the second-person singular negative imperative across several (Italo-)Romance varieties, its extension to the plural is only attested in those varieties where subordinating uses of the infinitive are radically attrited, such as in the southern Calabrian dialects under investigation here and in old Romanian. This case study therefore also offers a significant contribution to the study of the so-called Balkan Sprachbund by bringing to light a new feature associated with a typical Balkanism (viz. the reduced use of 
the infinitive), namely the possibility of reinterpreting the infinitival marker as a true, dedicated imperatival marker. ${ }^{29}$

\section{Acknowledgements}

This work is part of the Research Project RPG-2015-283 Fading voices in southern Italy: investigating language contact in Magna Graecia financed by The Leverhulme Trust. We are grateful to M.O. Squillaci and four anonymous reviewers for insightful comments, as well as to the audiences at the universities of Bucharest and Oxford where earlier versions of this paper were presented.

\section{References}

Aikhenvald, Alexandra. 2008. Imperative: The grammar of a clause type. Omotic utterance type, mood and attitude markers and linguistic typology. Unpublished ms., University of Leiden.

Alcázar, Asier and Mario Saltarelli. 2014. The Syntax of Imperatives. Cambridge: Cambridge University Press.

Auwera, Johan van der. 2010. Prohibition: Constructions and markers. In Dingfang Shu and Ken Turner (eds.), Contrasting Meaning in Languages of the East and West, 443-475. Tübingen: Narr.

Auwera, Johan van der and Ludo Lejeune, with Valentin Goussev. 2005. The prohibitive. In Matthew Dryer, Martin Haspelmath, David Gil, and Bernard Comrie (eds.), The World Atlas of Language Structures, 290-293. Oxford: Oxford University Press.

Auwera, Johan van der and Ludo Lejeune, with Umarani Pappuswamy and Valentin Goussev. 2013. The morphological imperative. In Matthew Dryer and Martin Haspelmath (eds.), The World Atlas of Language Structures Online. Leipzig: Max Planck Institute for Evolutionary Anthropology. (Available online at http://wals. info/chapter/70, accessed on 2019-03-08).

Bybee, Joan. 1985. Morphology: A Study of the Relation between Meaning and Form. Amsterdam: Benjamins.

Cavalcante, Rerisson. 2011. Negative imperatives in Portuguese and other Romance languages. In Julia Herschensohn (ed.), Romance Linguistics 2010. Selected Papers

29 In addition to the limited use of the infinitive, other 'Balkanisms' observed in the Calabrian varieties under investigation here are the genitive/dative syncretism (cf. the so-called dativo greco 'Greek-style dative') and the syntax of possessives in indefinite nominal phrases (cf. Ledgeway, 2013; Ledgeway, Schifano and Silvestri, 2018; 2020a, 2020b, in prep.). 
from the 4oth Linguistics Symposium on Romance Languages, 205-219. Amsterdam: Benjamins.

Chomsky, Noam. 2007. Approaching U from below. In Uli Sauerland and Hans Martin Gärtner (eds.), Interfaces + Recursion = Language?: Chomsky's Minimalism and the View from Syntax-Semantics, 1-29. Berlin: Mouton.

Chomsky, Noam. 2008. On phases. In Robert Freidin, Carlos Otero and Maria Luisa Zubizarreta (eds.), Foundational Issues in Linguistic Theory. Essays in Honor of Jean-Roger Vergnaud, 133-166. Cambridge, Mass.: мIт Press.

Crucitti, Pasquale. 1988. Vocabolario e frasario Mosorrofano-Santagatino. Soveria Mannelli: Calabria Letteraria Editrice.

Damonte, Frederico. 2010. Matching moods: Mood concord between CP and IP in Salentino and Southern Calabrian subjunctive complements. In Paola Benincà and Nicola Munaro (eds.), Mapping the Left Periphery, 228-256. Oxford: Oxford University Press.

De Angelis, Alessandro. 2013. Strategie di complementazione frasale nell'estremo Meridione italiano. Messina: SG в Edizioni.

Falcone, Giuseppe. 1973. Il dialetto romaico della Bovesia. Milan: Istituto lombardo di scienze e lettere.

Floricic, Franck. 2008. The Italian verb-noun anthroponymic compounds at the syntax / morphology interface. Morphology 18: 167-193.

Friedman, Victor A. 2006. Balkans as a linguistic area. In Keith Brown (ed.), Encyclopedia of Language and Linguistics, 2nd edn., 657-672. Oxford: Elsevier.

Friedman, Victor A. 2011. The Balkan languages and Balkan linguistics. Annual Review of Anthropology 40(1): 275-291.

Friedman, Victor A. and Brian D. Joseph. 2017. Reassessing Sprachbunds: A view from the Balkans. In Raymond Hickey (ed.), The Cambridge Handbook of Areal Linguistics, 55-87. Cambridge: Cambridge University Press.

Friedman, Victor A. and Brian D. Joseph. 2021. The Balkan Languages. Cambridge: Cambridge University Press.

Gardani, Francesco, Michele Loporcaro and Alberto Giudici. 2021. In and around the Balkans: Romance languages and the making of multi-layered languages. Journal of Language Contact 14(1):1-23.

Graffi, Giorgio. 1996. Alcune riflessioni sugli imperativi italiani. In Paola Benincà, Guglielmo Cinque, Tullio De Mauro, and Nigel Vincent (eds.), Italiano e dialetto nel tempo. Saggi di grammatica per Giulio C. Lepschy, 133-148. Rome: Bulzoni.

Han, Chung-Hye. 1998. The Structure and Interpretation of Imperatives: Mood and Force in Universal Grammar. Pennsylvania: University of Pennsylvania Institute for Research in Cognitive Science Technical Report Series (number 74).

Han, Chung-Hye. 1999. Cross-linguistic variation in the compatibility of negation and imperatives. West Coast Conference on Formal Linguistics 17: 265-279. 
Han, Chung-Hye. 2001. Force, negation and imperatives. The Linguistic Review 18: 289-325.

Ionescu, Emil. 2019. Negative imperatives in Eastern Romance languages: Latin heritage and Romance innovation. Zeitschrift für romanische Philologie 135: 845-865.

Isac, Daniela. 2015. The Morphosyntax of Imperatives. Oxford: Oxford University Press. Jones, Michael. 1992. Infinitives with specified subjects in Sardinian. In Christiane Laeufer and Terrell Morgan (eds.), Theoretical Analyses in Romance Linguistics, 295-309. Amsterdam: Benjamins.

Jones, Michael. 1993. Sardinian Syntax. London: Routledge.

Joseph, Brian. 1983. The Synchrony and Diachrony of the Balkan infinitive. Cambridge: Cambridge University Press.

Joseph, Brian D. 2010. Language contact in the Balkans. In Raymond Hickey (ed.), Handbook of Language Contact, 618-633. Oxford: Blackwell.

Kayne, Richard. 1991. Romance clitics, verb movement and PRO. Linguistic Inquiry 22: 647-686.

Kayne, Richard. 1992. Italian negative infinitival imperatives and clitic climbing. In Liliane Tasmowsky and Anne Zribi-Hertz (eds.), Hommages à Nicolas Ruwet, 300312. Ghent: Communication and Cognition.

Karanastasis, Anastasios. 1997. Grammatiki ton Ellinikon Idiomaton tis Kato Italias. Athens: Academy of Athens.

Katsoyannou, Marianne. 1995. Le parler gréco de Gallicianò (Italie). PhD dissertation, Université Paris VII.

Krapova, Iliyana and Brian Joseph (eds). 2019. Balkan Syntax and (Universal) Principles of Grammar. Berlin and Boston: De Gruyter Mouton.

Ledgeway, Adam. 1998. Variation in the Romance Infinitive. The Case of the Southern Calabrian Inflected Infinitive. Transactions of the Philological Society 96: 1-61.

Ledgeway, Adam. 2006. The dual complementiser system in Southern Italy: Spirito greco, materia romanza?. In Anna Laura Lepschy and Arturo Tosi (eds.), Rethinking Languages in Contact: The Case of Italian, 113-126. Oxford: Legenda.

Ledgeway, Adam. 2007. Diachrony and finiteness: Subordination in the dialects of Southern Italy. In Irina Nikolaeva (ed), Finiteness: Theoretical and Empirical Foundations, 335-365. Oxford: Oxford University Press.

Ledgeway, Adam. 2012. From Latin to Romance. Morphosyntactic Typology and Change. Oxford: Oxford University Press.

Ledgeway, Adam. 2013. Greek disguised as Romance? The case of Southern Italy. In Mark Janse, Brian Joseph, Angela Ralli, and Metin Bagriacik (eds.), Proceedings of the $5^{\text {th }}$ International Conference on Greek Dialects, 184-228. Patras: University of Patras.

Ledgeway, Adam. 2014. La morphologie flexionnelle de l'impératif des dialectes de l'Italie méridionale: La distribution de la métaphonie. In Jean Léo Léonard (ed), 
Morphologie flexionnelle et dialectologie romane: Typologie(s) et modélisation(s). Mémoires de la Société linguistique de Paris XXII, 13-33. Louvain: Peeters.

Ledgeway, Adam. 2016. Clausal complementation. In Adam Ledgeway and Martin Maiden (eds.), The Oxford Guide to the Romance Languages, 1013-1028. Oxford: Oxford University Press.

Ledgeway, Adam. 2019. The causative construction in the dialects of Southern Italy and the phonology-syntax interface. In Giulia Bellucci, Ludovico Franco and Paolo Lorusso (eds.), Linguistic Variation: Structure and Interpretation, 371-40o. Berlin: De Gruyter.

Ledgeway, Adam, Norma Schifano and Giuseppina Silvestri. 2018. Il contatto tra il greco e le varietà romanze nella Calabria meridionale. Lingue antiche e moderne 7: $95^{-133 .}$

Ledgeway, Adam, Norma Schifano and Giuseppina Silvestri. 2020a. Microvariation in dative-marking in the Romance and Greek varieties of southern Italy. In Anna Pineda and Jaume Mateu (eds.), Dative Structures and Beyond, 317-349. Berlin: Language Science Press.

Ledgeway, Adam, Norma Schifano and Giuseppina Silvestri. 2020b. I possessivi in italo-greco e italo-romanzo: parallelismi strutturali in un'area di contatto. Archivio Glottologico Italiano CV (I): 85-114.

Ledgeway, Adam, Norma Schifano and Giuseppina Silvestri. In prep. The Fading Voices of Southern Italy: A Case Study in Greek-Romance Language Contact in Magna Graecia. Oxford: Oxford University Press.

Loporcaro, Michele. 1986. L'infinito coniugato nell'Italia centro-meridionale: ipotesi genetica e ricostruzione storica. Italia Dialettale 49: 173-240.

Loporcaro, Michele. 1995. Recessività sintattica dell'infinito e vitalità morfologica della desinenza infinitivale in alcuni dialetti del reggino. In Roberto Ajello and Saverio Sani (eds.), Scritti linguistici e filologici: in onore di Tristano Bolelli, 331-358. Ospedaletto, Pisa: Pacini.

Maiden, Martin. 2006. On Romanian imperatives. Philologica Jassyensia II: 47-59.

Maiden, Martin, Adina Dragomirescu, Gabriela Pană Dindelegan, Oana Uță, and Rodica Zafiu. forthcoming. The Oxford History of Romanian Morphology. Oxford: Oxford University Press.

Manzini, Maria Rita and Leonardo Savoia. 2005. I dialetti italiani e romanci: Morfosintassi generativa. Volume III. Alessandria: Edizioni dell'Orso.

Mării, Ion. 1969. Note etimologice și morfologice. Cercetări de lingvistică 14: 54-56.

Martino, Paolo. 1980. L'isola grecanica dell'Aspromonte. Aspetti sociolinguistici. In Federico Albano Leoni (ed), I dialetti e le lingue delle minoranze difronte all'italiano. Atti dell'XI congresso internazionale di studi. Cagliari 27-30 maggio 1977, 305-341. Rome: Bulzoni. 
Matras, Yaron and Jeanette Sakel. 2007. Investigating the mechanisms of pattern replication in language convergence. Studies in Language 31: 829-865.

Maurer, Theodoro. 1968. O infinito flexionado português. Estudo histórico-descritivo. São Paulo: Editora Nacional.

McGregor, William. 1990. A Functional Grammar of Gooniyandi. Amsterdam: Benjamins.

Monod-Becquelin, Aurore. 1975. La Pratique linguistique des indiens trumai (HautXingu, Mato Grosso, Brésil). Paris: Centre National de la Recherche Scientifique.

Morosi, Giuseppe. 1878. I dialetti romaici del Mandamento di Bova in Calabria. Archivio Glottologico Italiano 4: 1-110.

Ouali, Hamid. 20o8. On C-to-T $\varphi$-feature transfer: The nature of agreement and antiagreement in Berber. In Roberta D'Alessandro, Gunnar Hrafnbjargarson and Susann Fischer (eds.), Agreement Restrictions, 159-180. Berlin: Mouton.

Papageorgiadis, Ianni. N.D. Grammatica degli idiomi del Sud Italia parlati in Grecia salentina (Puglia) e in Calabria. From the Grammar by A. Karanastasis published by the Academy of Athens in 1997. Web version in Italian. (Available at http://www. grecosuditalia.it, accessed 18/o9/20).

Poletto, Cecilia and Raffaella Zanuttini. 2003. Making imperatives: Evidence from Central Rhaetoromance. In Christina Tortora (ed), The Syntax of Italian Dialects, 175-206. Oxford: Oxford University Press.

Portner, Paul and Raffaella Zanuttini. 2003. Decomposing imperatives. Paper presented at IX Giornata di Dialettologia. University of Padua, 26 June 2003.

Puyau, Jean-Marie. 2013. Comprendre, parler, lire, écrire le béarnais. Cressé: Éditions des Régionalismes.

Ralli, Angela. 2021. Contrasting Romance and Turkish as donor languages: Evidence from borrowing verbs in Modern Greek dialects. Journal of Language Contact 14(1): $220-252$.

Rivero, María Luisa. 1994a. Clause structure and V-movement in the languages of the Balkans. Natural Language and Linguistic Theory 12: 63-120.

Rivero, María Luisa. 1994b. Negation, imperatives and Wackernagel effects. Rivista di Linguistica 6: 39-66.

Rivero, María Luisa and Arhonto Terzi. 1995. Imperatives, V-movement and logical mood. Journal of Linguistics 31: 301-332.

Rohlfs, Gerhard. 1968. Grammatica storica della lingua italiana e dei suoi dialetti. Morfologia. Turin: Einaudi.

Rohlfs, Gerhard. 1977. Grammatica storica dei dialetti italogreci. Munich: C.H. Beck.

Silva-Villar, Luis. 1998. Morphology and syntax of Romance imperatives: An incomplete history. Probus 10: 115-138.

Smith, John Charles. 2005. How to do things without junk: The refunctionalization of a pronominal subsystem between Latin and Romance. In Jean-Pierre Montreuil (ed), 
New Perspectives on Romance Linguistics: Selected Papers from the 35th Linguistic Symposium on Romance Languages (LSRL), Austin, Texas, February 2005. II: Phonetics, Phonology and Dialectology, 183-205. Amsterdam: Benjamins.

Smith, John Charles. 2011. Change and continuity in form-function relationships. In, Maiden Martin, John Charles Smith, and Adam Ledgeway (eds.), The Cambridge History of the Romance Languages. Volume 1: Structures, 268-317. Cambridge: Cambridge University Press.

Squillaci, Maria Olimpia. 2017. When Greek Meets Romance: A Morphosyntactic Analysis of Language Contact in Aspromonte. PhD dissertation, University of Cambridge.

Tekavčić, Pavao. 1972. Grammatica storica dell'italiano. Bologna: il Mulino.

Tomić, Olga M. 1999. Negation and imperatives. Catalan Working Papers in Linguistics 7: 199-206.

Tomić, Olga M. 2006. Balkan Sprachbund Morpho-syntactic Features. Dordrecht: Springer.

Tortora, Christina. 2014. A Comparative Grammar of Borgomanerese. Oxford, New York: Oxford University Press.

Tuite, Kevin. 1997. Svan. Munich: Lincom Europa.

Tuite, Kevin. 2018. The Svan Language. Unpublished ms., University of Montreal.

Violi, Filippo. 2004. Grammatica sintassi e lessico della lingua grecocalabra. Reggio Calabria: Iiriti Editore.

Zamfir, Dana-Mihaela. 2005-2007. Morfologia verbului în dacoromâna veche (secolele al XVI-lea-al XVII-lea), I, II. Bucharest: Editura Academiei Române.

Zanuttini, Raffaella. 1994. Speculations on negative imperatives. Rivista di Linguistica 6: 67-89.

Zanuttini, Raffaella. 1997. Negation and Clausal Structure. Oxford: Oxford University Press.

Zeijlstra, Hedde. 2006. The ban on true negative imperatives. In Oliver Bonami and Patricia Cabredo (eds.), Empirical Issues in Syntax and Semantics 6, 405-424. 